\title{
Rainfall trends and its implications on water resources management: a case study of Ogbomoso city in Nigeria
}

\begin{abstract}
A 37-year annual rainfall was collected from NIMET to study the trend of rainfall parameter and its implications on water resources management in the tropical city of Ogbomoso, Oyo State, Nigeria. The data was co-tested by both parametric and nonparametric statistical methods to determine the trend. The linear regression statistic and $\mathrm{M}-\mathrm{K}$, both, showed that rainfall trend in the study area is positive over the period with $\mathrm{R} 2$ of 0.001 while $\mathrm{M}-\mathrm{K}$ showed positive trend at 0.05 significance level. The results of the analysis implied that more rainwater was received in the city during the period under consideration. Thus, there was sustainable natural replenishment of both surface and subsurface water sources. The study further noted the possible negative effects of this finding including contamination of surface sources, destruction of life and properties through flooding including farmlands, human infrastructure and prevalence of diseases, among others. Thus, efforts should be made to ensure comprehensive water resource management. However, further research into the optimal utilization of the excess rainwater received in the area should be investigated.
\end{abstract}

Keywords: hydro-climatology, mann-kendall, climate change, water resources, rainfall trend
Volume 3 Issue 3 - 2019

\author{
Timothy Oyebamiji Ogunbode,' Paul \\ Ifatokun Ifabiyi² \\ 'Deptartment of Environmental Management and Control, \\ Bowen University, Nigeria \\ ${ }^{2}$ Department of Geography and Environmental Management, \\ University of llorin, Nigeria
}

\author{
Correspondence: Timothy Oyebamiji Ogunbode, \\ Deptartment of Environmental Management and Control, \\ Bowen University, Iwo, Osun State, Nigeria,
} Email taogunbode@gmail.com

Received: May 10, 2019 | Published: June 4, 2019

\section{Introduction}

The global awareness of climate change scenarios has invariably influenced the emphasy and persistent hydro-climatological research among scholars at different scales, most especially, rainfall studies. In the first place, the ultimate source of water to mankind is precipitation and the explanation of water resources in any given area are closely related to the rainfall over that area. ${ }^{1,2}$ In another instance, the need to ensure adequate protection of food production as observed by Krishan, et al. ${ }^{3}$ Also calls or such persistence. Apart from these observations, the recent incessant destruction of lives and property occasioned by flooding engendered by the unprecedented downpour has impacted on the sensitivity of man to the need for wide research in rainfall characteristics. Rainfall constitutes the major input into the hydrological cycle of any area. Of the rain that falls over an area, some percolates to replenish soil moisture and groundwater storage, some run off to join streams and rivers. Also, a substantial volume of water is lost through the processes of evapotranspiration. According to Dore ${ }^{4}$ and Krishan, et al. ${ }^{3}$ rainfall characteristics are static but highly varied over space and time. Egbinola and Amobichukwu ${ }^{5}$ revealed that annual rainfall range indicates the variability of annual rainfall and hence denotes how reliable the rainfall is in terms of its persistence as a constant and stable replenishing source of water in Ibadan metropolis. Olaniran ${ }^{6}$ and Olaniran and summer ${ }^{7,8}$ among others noted that there has been a progressive early retreat of rainfall over the whole country. In consistent with this pattern, it was reported that there has been a significant decline of rainfall frequency in September and October which repeatedly coincide with the end of the rainy season in the northern and central parts of the country. According to Udo-Inyang and Edem, ${ }^{9}$ one of the most significant climatic variations in the African Sahel since the late 1960s has been the persistent decline in rainfall.

The place of rainfall in hydrological cycle cannot be underestimated.
All other sources of water be it surface or subsurface, depend on rainfall for their replenishment. Thus, it is critical to understand rainfall dynamics on the surface of the earth. Among such features of rainfall that have been studied include its intensity, duration, amounts and trends over space and time for example, Cannarozzo, et al. ${ }^{10}$ Kwarteng, et al. ${ }^{1}$ Longobardi \& Villani, ${ }^{11}$ The understanding of the dynamics of rainfall both temporally and spatially is very crucial to achieve a sustainable water resource management. Water resource management implies the activity of planning, distributing and managing the optimum use of water resources. Water management is aimed at achieving one or more of the following: domestic water supply, industrial water use, irrigation farming, flood control, water quality control, among others. Ifabiyi \& Ojoye ${ }^{12}$ observed that the trends of rainfall have a great impact on the hydrologic cycle and therefore affect both the quality and quantity of water resources. They further stated that the concentration of greenhouse in the atmosphere has increased over the past few decades and this increase, according to them, is expected to increase rainfall characteristics such as the rainfall amounts, intensity, duration and frequency, which is also expected to alter the pattern of rainfall. Frederick \& Major ${ }^{13}$ and Ojoye $^{14}$ in buttressing this finding, also noted that climate change studies have revealed that droughts will become more rampant and extreme rainfall events more frequent if the trend is not controlled. It has been noted that such a study at local scale is preferable than at a larger scale because such a trend will have different implications at local scale than generalized observations which may not be applicable at local level. ${ }^{15}$ In addition to these observations, it is already noted that there is less certainty associated with the trends in precipitation. Thus, Houghton et al., ${ }^{16}$ concluded that precipitation amounts have increased over much of the globe, with a decrease over subtropical areas, but that the detection of these trends is problematic because they are neither temporally nor spatially uniform as noted by Folland et al. ${ }^{17}$ In view of these observations, consistent study of various characteristics of rainfall at different scales is important. To this end 
this research work has been embarked upon to examine the trends in rainfall in Ogbomoso, a city in Nigeria. The study will further reveal the implications of such trend on water resource management in the study area and probable remedial measures will be suggested to ensure sustainable management of this resource.

\section{Methodology}

\section{Study area}

Ogbomoso is located within the tropical region with distinctive wet (April -October) and dry seasons (November-March). Average temperature in the region is $31^{\circ} \mathrm{C}$ while total annual is about $1800 \mathrm{~mm}$. The temperature is persistently high with an annual range of about $5^{\circ} \mathrm{C}$. According to Adeboyejo and Abolade ${ }^{18}$ Ogbomoso is a precolonial urban center and the second largest city, both in terms of population and spatial extent in Oyo State, Nigeria (Figure 1). Ogbomoso, formerly the seat of Ogbomoso Local Government
Area, is currently made up of five LGAs namely Ogbomoso North, Ogbomoso South, Orire, Ogo-Oluwa and Surulere LGAs with their headquarters in Kinira-Ogbomoso, Arowomole, Ikoyi, Ajaawa and Iresaadu respectively. The city is located approximately $100 \mathrm{~km}$ north of Ibadan, the Oyo State capital, and roughly $80 \mathrm{~km}$ from both Kwara and Osun State capitals, Ilorin and Osogbo, respectively. ${ }^{18}$ Ogbomoso is dominated by both tropical rainforest to the southern part and derived guinea savanna to the northern part.

Ogbomoso, in the last few decades, has witnessed a tremendous urban expansion, the process which has led to the removal of natural vegetation for infrastructural development like roads, schools, residential buildings among others. Thus, urbanisation process has inflicted much on the environment that urban heat has increased abruptly. Even though, Ogbomoso is located in the tropics where the temperature is perpetually high all the year round, the urban heat island could have aggravated the rate at which water is vapourised in the city.

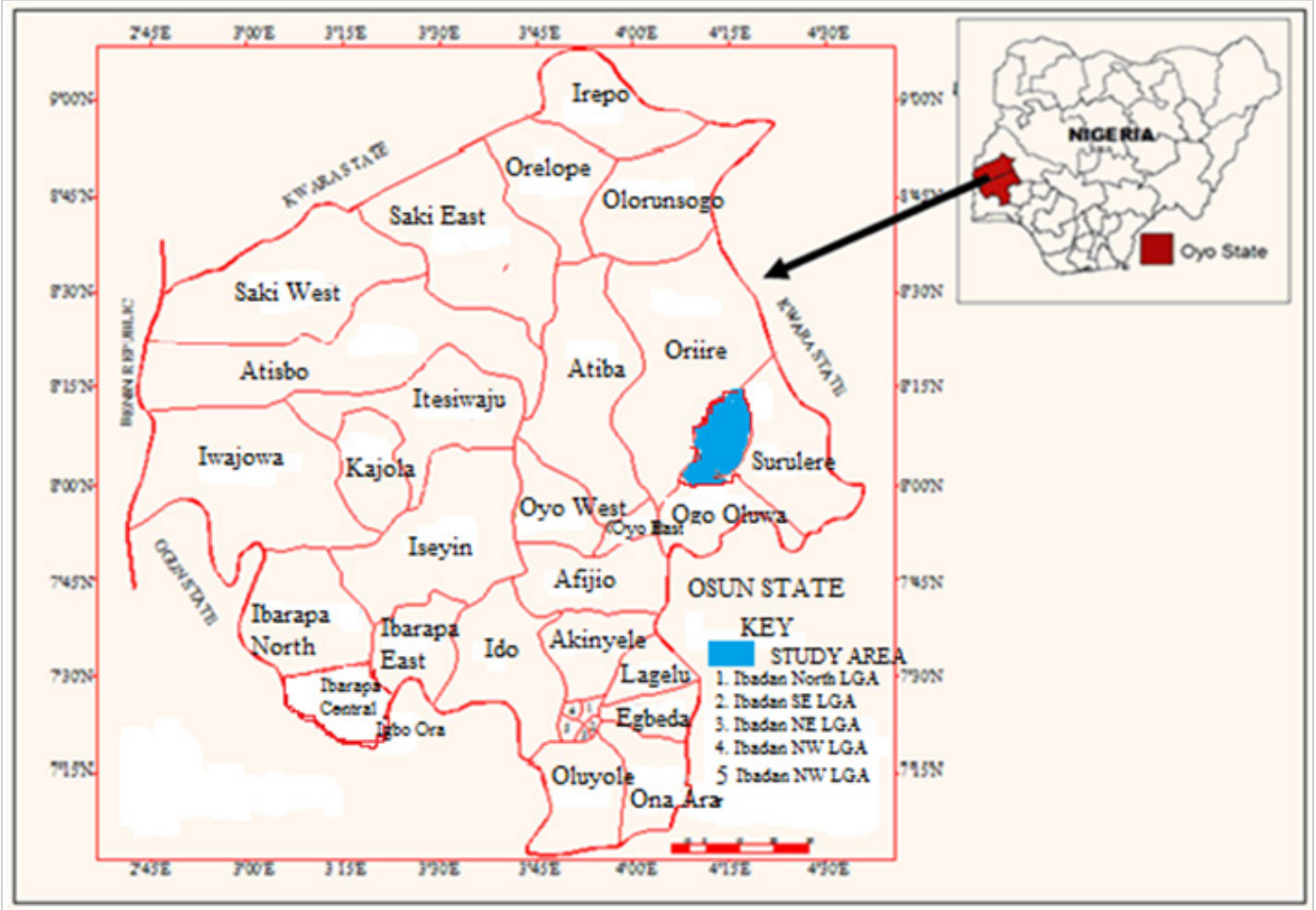

Figure 1 Oyo State Map showing the location of Ogbomoso (the study area).

(Inset: Map of Nigeria showing Oyo State)

\section{Data collection and analysis}

A 37-year rainfall data (1970-2006) collected from the Office of Nigeria Meteorological Agency in Ilorin was used in this study. Monthly rainfall totals were summed up to give annual rainfall total for each of the years studied. This is presented in Table 1.

\section{Method of analysis}

Regression analysis was applied to determine the linear trend of rainfall over the period. Linear regression analysis is one of the simplest methods of determining trends of an incidence in time series. The equation is given by:

$$
Y=a+b X
$$

Value of $Y$ when $X=0$

Where $\mathrm{X}$ is the explanatory variable (year) and $\mathrm{Y}$ is the independent variable (rainfall data). The slope line is $b$ and a is the intercept. Several authors have applied this parametric statistical method in water resources studies among which are Koutsouris et al. ${ }^{19}$ 
and Igwenagu. ${ }^{20}$ This analysis was carried out using SPSS software, Version 16.0. However, the validity of the results of linear regression is tested in this work as the data was co-tested with the use of MannKendall (M-K), a non-parametric statistic. Mann-Kendall statistic (S) was used to verify whether the trend in the data is positive or negative with their statistical significance. Al-Mashagbah and Al-Farajat ${ }^{21}$ noted that Mann-Kendall is a non-parametric statistical procedure that is well suited for analysing trends in data over time. According to Gilbert ${ }^{22}$ and Smith, ${ }^{23} \mathrm{M}-\mathrm{K}$ does not require any assumptions as to the statistical distribution of the whether normal, lognormal, etc and it can be used with datasets which include irregular sampling intervals and missing data. The positive values in $\mathrm{M}-\mathrm{K}$ statistic (S) indicates that there is increase in the incidence over time while negative values indicate a decrease over time. The statistic has been widely used by several researchers in rainfall studies. These include Longobardi and Villani, ${ }^{11}$ Shahid, ${ }^{24}$ Mondal et al., ${ }^{25}$ Al-Mashagbah and Al-Farajat, ${ }^{21}$ Dindang et al., ${ }^{26}$ Krishan, et al., ${ }^{3}$ among others. Microsoft Excel software was used to carry out the M-K analysis. M-K (S) is given as:

$$
\mathrm{S}=\sum_{\mathrm{i}=1 \mathrm{j}=1}^{\mathrm{n}-1} \sum_{j}^{\mathrm{n}} \operatorname{sgn}\left(\mathrm{x}_{j}-\mathrm{x}\right)
$$

The application of trend test is done to a time series $x_{\mathrm{i}}$ that is ranked from $i=1,2, \ldots \ldots \ldots, \mathrm{n}-1$ and $x_{\mathrm{j}}$, which is ranked from $j=i+1$, 2 .......n. Each of the data point $x_{i}$ is taken as a reference point which is compared with the rest of the data point's $x_{\mathrm{j}}$ so that $A=\pi r^{2}$

$$
\operatorname{Sgn}\left(x_{j}-x_{i}\right)=\left\{\begin{array}{c}
+1,>\left(x_{\mathrm{j}}-x_{\mathrm{i}}\right) \\
0,=\left(x_{\mathrm{j}}-x_{\mathrm{i}}\right) \\
-1,<\left(x_{\mathrm{j}}-x_{\mathrm{i}}\right)
\end{array}\right\}
$$

It has been documented that when $n \geq 8$, the statistic $\mathrm{S}$ is approximately normally distributed with the mean,

$$
E(S)=0
$$

The variance statistic is given as

$$
\operatorname{Var}(S)=n(n-1)(2 n+5)-\sum_{i=1}^{m} \operatorname{ti}(\mathrm{i})(\mathrm{i}-1)(2 \mathrm{i}+5) / 18
$$

Where $t_{i}$ is considered as the number of ties up to sample $i$. the test statistics $Z_{c}$ is computed as:

$$
Z_{c}=\left\{\begin{array}{c}
\frac{S-1}{\sqrt{\operatorname{Var}(S)}} \\
0, S \geq 0 \text { OR } \\
\frac{\mathrm{S}+1}{\sqrt{\operatorname{Var}(\mathrm{S})}}, S<0
\end{array}\right\}
$$

In order to determine the magnitude of the trends, Sen's method was applied. Sen's method estimates the true slope change overtime in a linear trend. The slope estimates of $\mathrm{N}$ pairs of data are computed by

$$
Q_{i}=X_{j}-X_{k} / j-k \text { for } I=1, \ldots . N
$$

Where $X_{j}$ and $X_{k}$ are data values at time $j$ and $k((j>k)$ respectively. The median of these $N$ values of $Q_{i}$ is Sen's estimator of slope. The Qi is computed by

$$
\begin{aligned}
& Q_{\text {med }}=Q(\alpha n+1) / 2 \quad \text { if } \mathrm{N} \text { is odd } \\
& Q_{\text {med }}=[Q n / 2+Q(n+2) / 2] / 2 \quad \text { if } \mathrm{N} \text { is even }
\end{aligned}
$$

$\mathrm{Q}_{\text {med }}$ is tested by a two-sided test at the $100\left(1 \_\alpha.\right) \%$ confidence interval and the true slope may be obtained by the non-parametric test. Apart from inferential statistics, the central tendencies of the data were also determined namely mean, range and the standard deviation of rainfall data

Table I Annual total rainfall in Ogbomoso from 1970 to 2006

\begin{tabular}{llllll}
\hline S/N & Year & $\begin{array}{l}\text { Annual total } \\
\text { rainfall(mm) }\end{array}$ & S/N & Year & $\begin{array}{l}\text { Annual total } \\
\text { rainfall(mm) }\end{array}$ \\
\hline 1 & 1970 & 938.3 & 20 & 1989 & 794 \\
2 & 1971 & 1106.8 & 21 & 1990 & 1020.1 \\
3 & 1972 & 1197.3 & 22 & 1991 & 1468.4 \\
4 & 1973 & 1460.8 & 23 & 1992 & 931.6 \\
5 & 1974 & 1256.5 & 24 & 1993 & 1157.9 \\
6 & 1975 & 1090.5 & 25 & 1994 & 1242 \\
7 & 1976 & 1078 & 26 & 1995 & 1409.2 \\
8 & 1977 & 928.9 & 27 & 1996 & 945.3 \\
9 & 1978 & 1209.4 & 28 & 1997 & 1334.4 \\
10 & 1979 & 1193.1 & 29 & 1998 & 1595.5 \\
11 & 1980 & 1237.1 & 30 & 1999 & 1539.3 \\
12 & 1981 & 1286.9 & 31 & 2000 & 990.3 \\
13 & 1982 & 1215.1 & 32 & 2001 & 697.1 \\
14 & 1983 & 1157.2 & 33 & 2002 & 902.3 \\
15 & 1984 & 1310.5 & 34 & 2003 & 1033.5 \\
16 & 1985 & 1133.3 & 35 & 2004 & 1294 \\
17 & 1986 & 1328.4 & 36 & 2005 & 1305.9 \\
18 & 1987 & 1213.7 & 37 & 2006 & 1303.8 \\
19 & 1988 & 898.9 & & & \\
\hline & & & & & \\
\hline
\end{tabular}

\section{Results and discussion}

As shown in Figure 2, the results of regression analysis revealed that there is positive trend in the pattern of rainfall over the period under study. The $\mathrm{R}^{2}$ of 0.001 indicates that the trend is positive. The range of rainfall incidence over the period shows that the least rainfall was in 2001 with $697.1 \mathrm{~mm}$ while the highest rainfall was recorded in 1998 with $1594.5 \mathrm{~mm}$ total rainfall. However, the years with rainfall totals less than $1000 \mathrm{~mm}$ were recorded in nine years of the entire period namely1970, 1977, 1988, 1989, 1992, 1996, 2000, 2001 and 2002. However, over the period, cases of water associated diseases/ deaths and other environmental hazards such as flooding, farm and other infrastructural destructions were recorded. 


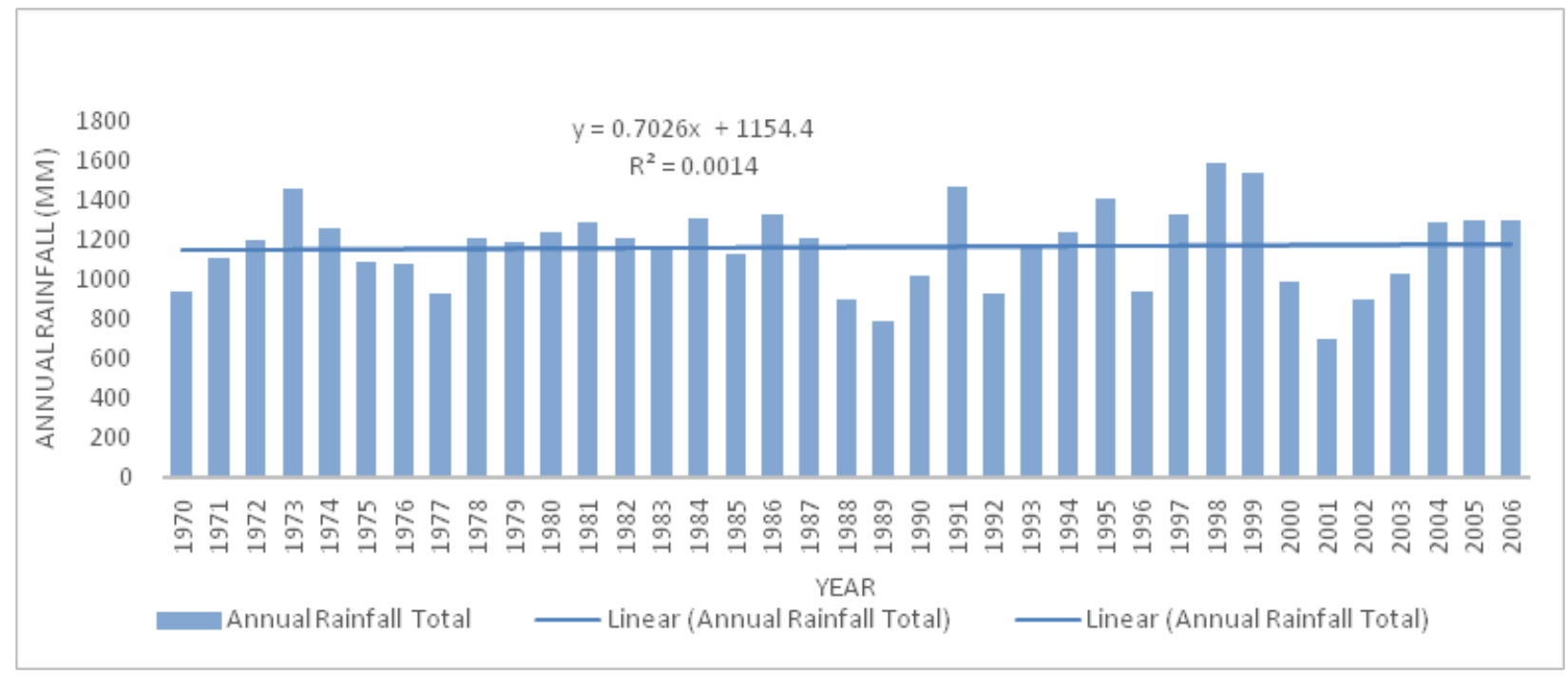

Figure 2 Mean annual rainfall pattern in Ogbomoso (1970-2006).

(Source:Author's fieldwork, 20I2)

\section{Summary of Mann-Kendall statistic}

The M-K analysis showed that

The number of positive differences $=391.0$

The Number of negative differences $=312.0$

$\mathrm{S}=391.0-512.0$

$\mathrm{S}=79.0$

Since Variance is determined by $(n(n-1)(2 n+5) / 18)$

Variance $=12107$,

Thus $79-1 \div \sqrt{ } 12107$

$\mathrm{Z}_{\mathrm{s}}=110.03$

$\mathrm{Z}_{\text {crit, }, 05}=126$ (by two-tailed test)

Thus, the result could be interpreted to indicate increasing (positive) trend since $Z_{\text {crit,.05 }}$ is greater than $\mathbf{Z}_{\mathrm{s}}$

The trend of rainfall in Ogbomoso, a city in the south western Nigeria of 37years was studied. The result of Mann-Kendall, nonparametric test, showed that there was an increasing trend in rainfall over the period studied. This result was also similar to the outcome of linear regression test which shows a slope with a positive trend, $\mathrm{R}^{2}=0.001$ over the period. These findings corroborated the report of Egbinola and Amobichukwu ${ }^{5}$ and that of Igwenagu ${ }^{20}$ for Enugu which discovered increasing trend in rainfall in their respective areas of study. However, the scenario of increasing trend in rainfall events is expected in view of the climate change. It has been discovered that more rainfall will be experienced in the tropics as a result of change in temperature. In buttressing this fact, Trenberth ${ }^{27}$ and Tollefson ${ }^{28}$ observed that there is a direct influence of global warming on precipitation. Trenberth ${ }^{27}$ further revealed that increased heating leads to greater evaporation and thus surface drying, thereby increasing the intensity and duration of drought. In view of this scenario, Trenberth ${ }^{27}$ showed that that the water holding capacity of air increases by about $7 \%$ per $1^{\circ} \mathrm{C}$ warming, which leads to increased water vapour in the atmosphere. The finding implies that the manifestation of the evidence global warming is already being experienced in Ogbomoso. This finding is also in agreement with the observation of Ren et al. ${ }^{29}$ which noted that there has been an increasing trend over both land and ocean from 1900 to 2008. In fact, it was discovered that the trends along latitude averaged over the oceans show very strong positive trends in the equatorial regions between $5^{\circ} \mathrm{N}$ and $15^{\circ} \mathrm{N}$ which are likely to be dominated by the Inter-Tropical Convergence Zone (ITCZ) ${ }^{30}$

However, the results of the analysis which showed an increasing rainwater supply in the area imply that efforts need to be put in place for a comprehensive environmental management, especially as it affects water resources. It is expected that water resource management would involve such measures that will ensure availability and accessibility of quality water for domestic use in the light of increased surface runoff that introduces pollutants into water sources, sustainable agricultural practice, especially irrigation farming, flood control through channelization of water passages. ${ }^{31,32}$ It is important that water resource managers rise up to the challenge imposed by water contamination that could arise so that the inhabitants of the city will have good access to potable water. Ifabiyi and Ogunbode ${ }^{33}$ had already revealed that accessibility to potable water in Oyo State, of which Ogbomoso is inclusive, had poor access to good quality water despite the availability of the resource, the finding attributed to poor water quality among others. More downpour would make the surface water sources more susceptible to pollution in view of the increased surface runoff. In buttressing this observation, cases of contamination of underground water in Ogbomoso has been reported. ${ }^{34}$ In view of this conclusion, Ojoawo and Kolade ${ }^{34}$ concluded that water supply in Ogbomoso is not fully supportive to human health. Thus strategies, such as public enlightenment and education, and direct involvement of 
stakeholders should be in place to enhance in improving the integrity of water. In another way, the advantage of more water from rainfall should be exploited by channeling it to domestic and industrial uses. Thus other water sources could be preserved for future.

Secondly, water resource/environmental managers need to ensure channelization of water passages to avert flooding especially at the downstream through the enlargement of river channels and streams. In the work of Aderogba, ${ }^{35}$ Ogbomoso is one of the southwestern Nigerian cities observed to be prone to flooding. It was noted that flooding frequency of an average of 11 days annually was noted in Ogbomoso and loss of properties worth of about 18 million naira was often involved. In addition, Adetunji and Oyeleye $\mathrm{e}^{36}$ had revealed that one of the problems of urbanization in Nigeria is flooding which they attributed to heavy rainfall induced by climate change. Also, in conjunction with the channelization is that effort should be put in place to protect wetlands from being excessively rendered damaged by water logging. This is necessary to protect farmlands that valuable for irrigation. The increasing trend in rainfall should be exploited to develop and boost rain-fed agriculture to enhance food and cash crop production. ${ }^{37}$

\section{Conclusion}

Climate change scenario has impacted on man and his environment globally. In view of this, an investigation into the trends of rainfall and its implication on water resources management in the tropical city of Ogbomoso, Nigeria was carried out. A 37-year annual rainfall total was subjected to both linear regression and Mann-Kendall statistics. The results of these analyses showed that there was a positive trend indicating increasing water supply over the period studied in the area. Thus, both surface and sub-surface water resources did not suffer natural replenishment. This means that strategic and comprehensive measures should be put in place to checkmate the negative implications of the increased rainwater supply through rainfall such as water pollution, flooding, wetland underutilization and destruction of farmlands among others. Suggested measures to control these menace include public enlightenment and education on controlling water pollution, channelization and dredging of river courses, development of rain-fed agriculture among others. The study suggested that further investigation be conducted on optimal utilization of excess rainwater received.

\section{Acknowledgments}

None.

\section{Conflicts of interest}

The author declares that there is no conflict of interest.

\section{References}

1. Kwarteng AY, Dorvlo AS, Vijaya Kumar GT. Analysis of a 27-year rainfal data (1977-2003) in the Sultanate of Oman. International J Climatology. 2009;29(4):605-617.

2. Ogunbode TO. Domestic water Utilisation and Management in selected rural areas of Oyo State, Nigeria. A PhD Thesis, Department of Geography and Environmental Management, University of Ilorin, Ilorin, Nigeria. $2015 ; 265$.
3. Krishan G, Chandniha SK, Lohani AK. Rainfall trend analysis of Punjab, India using statistical non-parametric. Current World Environment. 2015;10(3):792-800.

4. Dore MHI. Climate change and changes in global precipitation patterns: What do we know? Environmental International. 2005;31(8):1167-1181.

5. Egbinola CN, Amobichukwu AC. Climate variation assessment based on rainfall and temperature in Ibadan, South western, Nigeria. J environment and Earth Science. 2013;3(11):32-45.

6. Olaniran OJ. Changing patterns of rain-days in Nigeria. Geo Journal. 1990;22(1):107-137.

7. Olaniran OJ, Summer GN. Long term variation of annual and growing season rainfalls in Nigeria. Theor Appl Climatol. 1990;41(1-2):41-53.

8. Olaniran OJ, Summer GN. Climate change in Nigeria: Change in the rainfall receipt per rain day. Weather. 1989;44(6):242-248.

9. Udo-Inyang CU, Edem DI. Analysis of rainfall trends in Akwa-Ibom State, Nigeria. J Environment and Earth Science. 2012;2(8):60-70.

10. Cannarozzo M, Notto LV, Viola F. Spatial distribution of rainfall trends in Sicily(1921-2000). Physics and Chemistry of the Earth. 2006;31(18):2101-1211.

11. Longobardi A, Villani P. Trend Analysis of annual and seasonal rainfall time series in the Mediterranean area. International J Climatology. 2009;30(10):1538-1546.

12. Ifabiyi IP, Ojoye S. Rainfall trends in the Sudano-sahelian ecological zone of Nigeria. Earth Science Research. 2013;2(2):194-202.

13. Frederick KD, Major DC. Climate Change and Water Resources. Climatic Change. 1997;37(1):7-23.

14. Ojoye S. Climate Change impact on water resources and adaptation strategies in the Sudano-sahelian zone of Nigeria. A PhD thesis, Department of Geography and Management, University of Ilorin, Ilorin, Nigeria. 2012.

15. Barua S, Muttil N, Ng AWM, et al. Rainfall trend and its implications for water resource management within the Yarra River catchment, Australia. Hydrol Process. 2013;27(12):1727-1738.

16. Houghton JT, Ding Y, Griggs DJ, et al. Climate Change 2001: The Scientific Basis. Cambridge University Press. 2001;944.

17. Folland C, Coauthors. Observed climate variability and change. In: Houghton et al. Editors. Climate Change 2001: The Scientific Basis. Cambridge University Press. 2001;99-181.

18. Adeboyejo AT, Abolade O. Household responses to urban encroachment on the rural hinterland in the Ogbomoso urban fringe, Nigeria. In: de Shabiniin A, et al. Editors. Urban Population-Environment dynamics in the developing world: Case studies and lessons learned, Paris, Committee for International Cooperation in National Research in Demography (CICRED). 2009;316.

19. Koutsouris AJ, Destouni G, Jarsjo J, et al. Hydro-climatic trends and water resources management implications based on multi-scale data for the Lake Victoria region, Kenya. Environmental Research Letters. 2010;5(3):12-18.

20. Igwenagu CM. Trend analysis of rainfall pattern in Enugu State, Nigeria. European J Statistics and Probability. 2015;3(3):12-18.

21. Al-Mashagbah A, Al-Farajat M. Assessment of spatial and temporal variability of rainfall data using Kriging, Mann-Kendall and the Sen's slope estimates in Jordan from 1980 to 2007. Journal of Environmental and Health Sciences. 2013;5(10):611-618. 
22. Gilbert RO. Statistical methods for environmental pollution monitoring Van Nostrand, Rehinholds, New York. 1987.

23. Smith LC. Trends in Russian Arctic river-ice formation and break up, 1917 to 1994. Physical Geography. 2000;20(1):46-56.

24. Shahid S. Rainfall variability and the trends of wet and dry periods in Bangladesh. Int J Climatology. 2010;30(15):2299-2313.

25. Mondal A, Kundu S, Mukhopadhyay A. Rainfall trend analysis by MannKendall Test: A case study of north-eastern part of Cuttack District, Orissa. International J Geology, Earth and Environmental Sciences. 2012;2(1):70-78

26. Dindang $\mathrm{A}$, Taat $\mathrm{AB}$, Beng $\mathrm{PE}$, et al. Statistical and Trend analysis of rainfall data In Kuching, Sarawak from 1968-2010. Malaysian Meteorological Department and Ministry of Science, Technology and Innovation, Research Publication No. 6. 2013.

27. Trenberth KE. Changes in precipitation with climate change. Climate Research, 2011;47:123-138.

28. Tollefson J. Global warming already driving increases in rainfall extremes. Nature. 2016

29. Ren LP, Arkin P, Smith TM, et al. Global precipitation trends in 1900-2005 from a reconstruction and coupled model simulations. Journal of Geophysical Research and Atmosphere. 2013;118(4):1679-1689.

30. Barry RG, Chorley RJ. Atmosphere, Weather and Climate. London: Routledge. 1992;392:1727-1738.
31. Ojo O, Oni F, Ogunkunle O. Implications of climatic variability and climate change on water resources availability and water resources management in West Africa. Water Resource Systems-Water Availability and Global Change (Proceedings of symposium held during IUG at Sapporo). IAHS Publication No. 280. 2003;37-47.

32. Adams RM, Peck DE. Effects of climate change on water resources. Choices (A magazine of food, farm and resource issue). 2008;23(1):12-14.

33. Ifabiyi IP, Ogunbode TO. The use of composite water poverty index in assessing water scarcity in the rural areas of Oyo State, Nigeria. International J Science and Technology, AFFREV STECH. 2004;3(2):51-65.

34. Ojoawo SO, Kolade TL. Contamination levels of some selected wells in Ogbomoso South Local government Area, Nigeria and the implication on human health. J Water Resources and Protection. 2013;5(7):653-668.

35. Aderogba KM. Substantive causes and effects of floods in south western Nigeria and sustainable development of the cities and towns. $J$ Emerging Trends in Educational Research and Policy Studies (JETERAS). 2012;3(4):551-560.

36. Adetunji MA, Oyeleye OI. Evaluation of the causes and effects of flood in Apete, Ido Local Government Area, Oyo State, Nigeria. J Civil and Environmental Research. 2013;3(7):19.

37. Trenberth KE. The impact of climate change and variability on heavy precipitation, floods and droughts. In: Anderson MG, Editors. Encyclopedia of Hydrological Sciences. John Wiley \& Sons, Ltd. 2005. 